\title{
APPLIED FOOD SAFETY REQUIREMENTS IN THE CASE OF ORGANIC FARMERS' FOOD PROCESSING ACTIVITY AND THEIR EFFECTS ON THE PRODUCTION ${ }^{1}$
}

\author{
Nagyné Pércsi Kinga \\ associate professor \\ Faculty of Economics and Social Sciences, Szent István University \\ E-mail: nagyne.percsi.kinga@gtk.szie.hu
}

\begin{abstract}
The improvement of the organic farming is a basic aim of the national agricultural policy for years. The new CAP 2014-2020 also strengthen the central role of organic agriculture in the fight against climate change, the protection of the environment and the preservation of biodiversity. The organic farms are usually small scale enterprises so their development also relating to the improvement of the Short Food Supply Chains which is supported in the frame of the Rural Development Programme. The health related characteristics of the food product gained on importance in the past decade among the European consumers. The organics has more favourable characteristics from this aspect as compared to the conventional food, which is due to the organic producing principles. However the food safety, hygienic characteristic of the food stemming from local small scale farmers are similar to the organics. The aim of the article is to reveal the judgement of the applied rules by the organic and small scale farmers and to find the main differences in food safety level in the two product categories in this field.
\end{abstract}

Keywords: difference between local products, organic requirements, food safety aspects

JEL classification: $Q 19, R 10$

LCC code: $S 1$

\section{Introduction}

The organic farms are commonly small scale farms, so during analysis of requirements for organic food production we should take into consideration the regulation of small scale farmers' food production and sale because it affects the organic farming from close. In Hungary the rules set in the regulation of the food safety conditions for the sale in local farmers' markets (51/2012. Rural Development Ministry Decree), the regulation on the conditions of small scale producing, processing and marketing (52/2010 Ministry of Agriculture and Rural Development Decree) and the government decree for fairs, markets and shopping centres (55/2009 Government Decree) contain relevant requirements. The special national regulations and easier rules helped the organic and conventional farmers a lot. It is very important that the regulations have strict limits for the size in this category "small scale producers" and it can be outgrew easily.

These simplified procedures on hygiene were introduced for small scale farmers in order to facilitate direct sales to consumers. However, for small family farm businesses, administrative and organisational burdens remain high (obligation to issue an invoice, registration of pesticides treatments, production and sales registers, manufacturing data sheet, cold chain) these more administrative tasks do not affect the organic farmers so much because they are accommodate such registration during the certification processes and controls. According to the survey data

\footnotetext{
${ }^{1}$ This work was created in commission of the National University of Public Service under the priority project KÖFOP-2.1.2VEKOP-15-2016-00001 titled „Public Service Development Establishing Good Governance” and Szent István University.
} 
used more than $50 \%$ of the interviewed organic farmers found that one of the most important obstacle in the way of development are the complicated support application procedures and the bureaucracy. According to the domestic regulations local farmers market where small scale producers can sell their produce within the county, or in a $40 \mathrm{~km}$ radius area around the market, or in Budapest (Nébih, 2012). The abovementioned government and ministry regulations also define the compulsory legal procedures to start a market. The biggest organic market is situated in Budapest, the organic producers should transport their product from different regions of the country. The most important reason for the localization of the organic market can be found in the results of the following survey which was made among Hungarian population by Medián Market Research Institute. The social effect of direct buying from local producers is considered important mostly by the highest educated consumers while global impact of purchases is solely considered by the highest income households. Paying an extra 10 percent for any politicalethical reason is not really considered by the average population. While more than half of the respondents would be willing to pay an extra ten percent for good quality and healthy products, solidarity purchasing (improvement livelihood of local food producers) would be a reason to pay an extra price for only 37 percent, and solidarity with producers in other parts of the world for only 18 percent. Altogether paying a price premium to improve livelihoods of small farmers seems acceptable only in Budapest, to the most educated and wealthiest people. (Medián, 2012 in Kneafsey et al, 2013) In the case of organics precisely the so called "process quality" components dominate at purchasing. So the higher quality sometimes cannot be realized in the end product as for example higher nutrition value, but you have inclination to pay a price premium for the way of production, for the sustainable methods of production and for the animal welfare.

Gódor and Bakos also found that the traditions and health conscious consuming patterns influence the different areas in the country in various extent (Gódor-Bakos, 2017). The main principles for organic farming and food processing include (IFOAM, 2001):

- the production of food of high quality in sufficient quantities,

- operation within natural cycles and closed systems as far as possible, drawing upon local resources,

- the maintenance and long term improvement of the fertility and sustainability of soils,

- the creation of a harmonious balance between crop production and animal husbandry,

- the securing of high levels of animal welfare,

- the fostering of local and regional production and supply chains, and

- the provision of support for the establishment of an entire production, processing and distribution chain that is both socially and ecologically justifiable.

These basic principles provide organic farming with a platform for ensuring high levels of food safety, even though the safety of food is not directly specified in the principles. These principles also underpin the strong relations between local food systems and organic farming. The organic farming has stricter rules for production from food safety aspect. High standards of product safety in organic foods are promoted by lower nitrogen use (which reduce nitrate concentration in food), the ban on pesticides (which results in almost no pesticide residues), and the ban on prophylactics and the requirement for double retention times in animal production systems (to ensure low concentration of medicine residues) (Hansen, 2002). Otherwise the animal health requirements of feeding and keeping are similar to the conventional animal husbandry. This later mentioned is extremely important in the case of poultry keeping. In particular, regulation of the processing of organic foods results in higher product safety due to a limit of no more than $5 \%$ non-organic components, and the ban on irradiation, colouring agents, sweeteners, synthetic additives, flavouring, GMOs and trans fatty acids. There seems to be a trend towards higher 
agri-foodsystem safety in organic compared to conventional farming systems (Hansen, 2002). After the review of the basic differences in requirements I would like to focus on the particular special rules in the next part of this article.

\section{Special important hygienic rules in small scale farming}

At first the basic definitions and terms should be discussed to understand the sense of the requirements. According to the EU Food Hygiene Regulation (852/2004/EC regulation) the basic food product should not be processed and should be sold directly. The live animals and also raw milk should be regarded as basic food product. The basic food product can be processed further after their production, gathering. According to the extent of such processing they can be handled as unprocessed or processed food products. In the case of unprocessed product the processing activity can be grounding, skinning, cutting, cleaning, and chilled (for example meat chop, fish fillet). The processed products goes through such handling which change their original characteristics basically, like heating, smouldering, curing, pickling, drying, marinating, extracting (for example pasteurized milk, sausage, marmalade). The two above mentioned categories of products should meet different requirements (Nébih, 2012). In the followings only some special requirement of the milk and meat processing will be introduced because they are hazardous food products, many food safety incident relating to them. In 2011 a new regulation was issued by the Hungarian Rural Development Ministry on the food safety conditions of the production and sale of catering products $(62 / 2011 \mathrm{VM})$ which rationalize many food safety requirements applied in catering.

According to this national regulation the catering enterprises are allowed to purchase raw milk, before this regulation it was prohibited for them. The above mentioned regulation also contains rules relating to the purchasing condition of small scale farmers' food products which can also help the sale of local food. The basic and processed local animal products should be stemming from animal population controlled by official veterinarian who issued an official veterinary certificate. This certificate proves that the population is involved in the obligatory immunization programmes. The small scale farmer should slaughter the poultry and rabbits on the spot of production. The meat inspection should be done and the relating certification should be issued by the official or the authorized veterinarian. The small quantity direct sale is an exemption from the above mentioned rules, however only poultry and rabbits controlled by vet and accompanied by official certification can be sold for catering. The small scale farmer should have the cattle, pig, sheep, goat, ostrich, emu raised in the farms slaughtered by a certified slaughterhouse. In this case the official vet inspects the animals on the spot and issues the certifications, which should be reserved for 2 years.In the case of milk production the hygienic rules connecting to the milking processes, the cooling and the avoiding of cross contaminations. There is a special rule for the labelling of raw milk and products made from raw milk without tempering. The marking "raw milk, boiling before consuming is needed" or "product made from raw milk" should be attached to these products in unambiguous way.

\section{Methods}

A survey was made among the organic farmers who sell their product direct on the organic market of Biokultúra Alliance in Budapest and controlled by the Biokontroll Ltd. A semi structured interview was made with 10 farmers in September 2017. On the homepage of the Biokultúra Alliance the list of the seller of the Biokultúra Organic Market can be found but this list contains also those who are only merchandizers. According to this list there are 97 sellers on the market, but many of them only merchandizer and some of them only sell handicraft products (only folk weave for example). The applied questionnaire contained 51 questions, 
most of which connected to the characteristics of direct selling and the organic market. The farmers had also the opportunity to tell their opinion about the future prospects of the sector and they could introduce their development plans, intentions. The way of asking questions was personal request. However it was very time consuming, this method gave opportunity for the farmers to give additional information relating to the particular questions and to avoid misinterpretation.

A couple of months before this survey another was made among the Hungarian conventional "native producers", so small scale farmers stemming from different regions of Hungary. Altogether 8 case studies could be used. Two rounds of semi-structured interview was made. In the first questionnaire the general characteristics of the farms were surveyed, the questions connected to the legal status of the farm, the land property and land use, the type of production, the marketing channels and finally the socio-demographic information. On the basis of the first survey a more specialized questionnaire was compiled to the selected farmers and its questions relating to the production safety, marketing channels and the future development plans. The farmers had the opportunity to tell their opinion relating to the topics in both cases. Every farmer is a licensed traditional small-scale producer and nobody is planning to change this legal status. 3 occupy with fruits and vegetable production, 3 of them keep animals, one of them occupies with honey bee keeping, and one with cereal planting on a land of 90 hectares. One of the animal keeping farms deals only with milk production. If we compare the results of this too survey we can find interesting differences and similarities.

\section{Results}

Most of the surveyed organic farmer sell their products only on the analysed organic market. Every organic farmers agreed in that it is hard to get in this market it is a closed community. All of them are involved in the direct selling more than 10 years. This segment of the farmers usually meet self-conscious consumer because they use the traditional producers' market as a main marketing channel or they are integrated in community farming, the so called box system. Only three of the surveyed 10 organic farmers has experiences with export markets and nobody has connection with retail chains. They do not intend to be the supplier of such chains this aim is not harmonize with their long-term development plans. All of the organic farmers agreed in that the regulation connecting to the conditions of product producing, processing and marketing by small scale farmers gives a good opportunity for the organic producers. One of the two interviewed organic goat milk producers claimed that they invest in a well-equipped processing plant before the issuing of the regulations and it was very expensive. He found that the control by the NÉBIH (National Food Chain - Safety Office) is utmost strict.

One of the organic fruit and vegetable producer said that they outgrew the frame of small scale farming scheme in the meanwhile and they had to change the category of farming. This kind of farming can be a great help at the beginning in case of a starting organic farm. The most important profile of the surveyed organic farmers was the organic fruit and vegetable production. 6 organic farmers are mainly involved in fruits and vegetable sector, one has a large scale of supply, from grey cattle to grain and he also deal with fruit and vegetables, so the farm has a mixed profile. One of them occupy with honey bee keeping and produce honey and other relating processed products and further two deal with milk production. The products stemming from different regions of the country. It can be stated that the organic farmers view the situation of the market optimistic because they usually meet self-conscious consumers who visit this market because they know the advantages of the organic products and has an inclination to pay more for it. 
The most important limiting factors which the organic farmers mentioned were the barriers to entry, the problems with the stable quantities and the high production costs according to the organic farmers. The organic farmers did not agree with the statement "the food safety can be improved through direct sale"., but they think one of the most important influencing factor of buying organic is the positive health impact of this kind of food. It should be also highlight that they find the organic label very useful, the consumers search for various organic labels and the additional information given by this label can increase food-safety. They thought that the regulations relating to organic farming can be met easily, they are not complicated. $40 \%$ found the bureaucracy as a limiting factor only in case of support application procedures. The survey among the conventional farmers showed that they feel that they should not make too much effort to achieve the organic status, because they prefer environmental friendly protection methods and use a minimum quantity of pesticides and other chemicals in production. They found that to get the certification would be cost demanding and there is no solvent demand for organic in those rural areas where they sell their products. Every interviewed fruits and vegetable producers thought this. Only one conventional had quality problems relating to direct sale, namely the milk producers. They had problems with the bottles and the cooling and storing of milk. In this circle of farmers the requirements set by the regulation sometimes cause high administrative and organisational burdens (registration of pesticides treatments, production and sales registers, manufacturing data sheet, cold chain), but this is the consequence of their size. The conventional farmers agreed in that the hygienic rules are useful and reasonable. Only one of them has other opinion. This farmer keeps animals (sheep, goat, cattle) and has problems with the requirements of live animal transport in case of small quantity. He also complained on the small scale meat sale requirement, he found them unrealistic. Only one fruit and vegetable producer should not control pesticide residues because the low level of pesticide use. The animal keeping farmers found the cost of examination unreasonable high. However according to the relevant literature it is a common problem and relating to the small size (Benedek et al, 2014). It is also important to add that it is a very positive phenomenon that the farmers accept the hygienic rules, because we can found negative examples also when the farmers do not understand the logic of the rules and think they are unnecessary and bothersome (Ter Kuile, 2012). It is interesting that every conventional farmers said that the consumers are inclined to pay higher price for the higher quality and food safety level of the products. 6 of 8 added that promotions or special market (handicraft market) have positive effect to the prices.

\section{Conclusion(s)}

In 2006 simplified procedures on hygiene were introduced for small scale farmers in order to facilitate direct sales to consumers. I think the regulations provide for the needed level of food safety and does not means obstacles in the way of development. The legislation finally could find the balance between the protection of public health and helping small scale farmers' marketing. For example the dairy products can be made from raw milk, but you should indicate it. The consumers will decide if they buy or refuse it. In parallel other sector's hygienic rule was also simplified and gave an opportunity for sale. For example from 2011 the catering enterprises can accept raw milk also, however they are obliged to boil it as soon as possible. This new rules gave an opportunity for small farmer to sell their product to them. So there is a coherency between the relating regulations. These basic organic principles provide organic farming with a platform for ensuring high levels of food safety, even though the safety of food is not directly specified in the principles.

It can be stated that the interviewed organic farmers view the development of the market optimistic because they usually meet self-conscious consumers who visit this market because they know the advantages of the organic products and has an inclination to pay more for it. The 
most important limiting factors which the organic farmers mentioned were the barriers to entry, the problems with the stable quantities and the high production costs. The surveyed organic farmers thought that the regulations relating to organic farming can be met easily, they are not complicated. The conventional farmers also agreed in that the hygienic rules are useful and reasonable. Only one of them has other opinion. These high acceptance level enhance the food safety status of such products because there is a strong inclination to keep them. It is interesting that every conventional farmers said that the consumers are inclined to pay higher price for the higher quality and food safety level of the products. The interviewed conventional farmers feel that they should not make too much effort to achieve the organic status, because they prefer environmental friendly protection methods and use a minimum quantity of pesticides and other chemicals in production. They found that to get the certification would be cost demanding and there is no solvent demand for organic in those rural areas where they sell their products. Every interviewed fruits and vegetable producers thought this. This underpin that sometimes there is only slight difference between the food safety characteristics of the two product circles. But the high entrance cost and the lack of demand retain the farmers to change profile.

\section{Acknowledgement}

This work was created in commission of the National University of Public Service under the priority project KÖFOP-2.1.2-VEKOP-15-2016-00001 titled „Public Service Development Establishing Good Governance" and Szent István University.

\section{References}

1. Benedek, Zs. - Fertő, I.- Baráth, L. - Tóth, J. (2014): Differences of small-scale farmers and the related short agri-food value chains. An empirical evidence from Hungary Mühelytanulmányok, MTA, 2014

2. Goda, P; Káposzta, J; Péli, L. (2013): Case study on spider-net enthrophy investigation in rural areas. REVIEW ON AGRICULTURE AND RURAL DEVELOPMENT 2: 1 pp. 296-302., 7 p. (2013) ISSN 2063-4803 296

3. Gódor, A. K. - Bakos, I. M. (2017): A magyar egészségi állapot és élelmiszerfogyasztás föbb összefüggései. A FALU 32: pp. 43-51. 2017.

4. Hansen, B. - Fjelsted Alrøe, H. - Steen Kristensen, E. - Wier, M. (2002): Assessment of food safety in organic farming. DARCOF Working Papers no. 52 January 2002

5. IFOAM(2001): Basic Standards for organic farming and processing, 2001.

6. Káposzta, J; Ritter, K; Nagy, H. (2016): Local Economic Development in Transition Economies: A Tool for Sustainable Development of Rural Areas. In: Vasily, Erokhin (szerk.) Global Perspectives on Trade Integration and Economies in Transition. Hershey (PA), Amerikai Egyesült Államok: IGI Global, (2016) pp. 281-298., 18 p. ISBN: 9781522504528

7. Kneafsey, M. - Venn, L. - Schmutz, U. - Balázs, B. - Trenchard, L. - Eyden - Wood, T. - Bos, E. - Sutton, G. - Blackett, M. (2013): Short Food Supply Chains and Local Food Systems in the EU. A State of Play of their Socio-Economic Characteristics. JRC, 2013 (https://ec.europa.eu/agriculture/sites/agriculture/files/quality/local-farmingdirect-sales/pdf/com-report-12-2013 en.pdf).

8. Medián (2012) Attitudes towards the social effects of food purchasing. Report for ESSRG. Manuscript. quoted by Kneafsey et al, 2013.

9. Nagy, H; Káposzta, J. (2004): A new challenge to be faced: Regional inequalities. BULLETIN OF THE SZENT ISTVÁN UNIVERSITY (GÖDÖLLÖ) 2004: 1 pp. 163 173., 11 p. (2004) ISSN 1586-4502. 
10. Nébih (2012): A helyi termelöi piacokon történő árusítás élelmiszer-biztonsági feltételeiröl szóló 51/2012. (VI. 8.) VM rendelet (Magyar Közlöny 2012/68.) a vásárokról, a piacokról, és a bevásárlóközpontokról szóló 55/2009. (III. 13.) Kormányrendelet (Magyar Közlöny 2009/30.) és a kistermelői élelmiszer-termelés, előállítás és -értékesítés feltételeiről szóló 52/2010. (IV. 30.) FVM rendelet (Magyar Közlöny 2010/66.) tükrében. AROP-2216-Jogalkalmazás javítás a mezőgazdasági szakigazgatásban 2., Nemzeti Élelmiszerlánc-biztonsági Hivatal, 2012.

11. Ter Kuile, B. (2012): Food safety problems specific to the short chain selected case studies from the Netherlands. Food Safety of Short Food Supply Chain, Symposium SciCom 2012. 